\title{
Response of Indian mustard to Nutrients and Plant Growth Regulators: The Influence on Yield, Available Soil P Balance and P Recycling through Residues
}

\author{
R.K. Dubey ${ }^{1 *}$, R.C. Dhaker², S.L. Mundra ${ }^{3}$, R.C. Tiwari², \\ S.K. Dubey ${ }^{1}$ and Reena Dubey ${ }^{4}$ \\ ${ }^{1}$ ICAR-Indian Institute of Soil and Water Conservation, Research centre, Chhalesar, Agra 282 \\ 006, Uttar Pradesh, India \\ ${ }^{2}$ Mewar University, Gangrar, Chittorgarh 312-91, Rajasthan, India \\ ${ }^{3}$ Department of Agronomy, Rajasthan College of Agriculture, Maharana Pratap University of \\ Agriculture and Technology, Udaipur 313 001, Rajasthan, India \\ ${ }^{4}$ G.B. University of Agriculture and Technology, Pantnagar, Nainital, Uttrakhand, India \\ *Corresponding author
}

\section{A B S T R A C T}

Poor oilseed productivity linked huge edible oil import by India are intimately interlinked and critically relate to over exploitation of agricultural soils, inadequate and imbalanced

Keywords

Available soil $\mathrm{P}$, Indian mustard,

Plant growth regulator, Residue recycling, Soil phosphorus balance.

Article Info

Accepted:

26 June 2017

Available Online:

10 August 2017 fertilization, restricted use of manures, residues and bio-fertilizers, unfavourable climatic conditions and physiological and genetic constraints associated with oilseeds. Plant growth regulators (PGRs) mitigate a variety of abiotic and biotic stresses and a strong synergistic interaction between auxins and brassinosteroids (BRs) is also widely reported but commercial exploitation of this interaction has yet not been attempted in actual field studies. Therefore, eight nutrient treatments comprising of 75 and $100 \%$ recommended dose of fertilizers (RDF) and their combinations with $5 \mathrm{t}$ farm yard manure $\mathrm{ha}^{-1}(\mathrm{FYM})$, bio-fertilizers (Azotobacter + PSB) and FYM + bio-fertilizers as well as four PGRs (water spray, brassinolide/BR $0.5 \mathrm{ppm}$, Indole 3 acetic acid/IAA $50 \mathrm{ppm}$ and BR $0.5+$ IAA 50 ppm) were evaluated on medium clay loam soils of Udaipur during winters of 2012 and 2013 in a split plot design replicated thrice. Results illustrate that among nutrient treatments, $100 \%$ RDF + FYM + bio-fertilizers registered significantly higher pooled seed and stover yield (3231 and $13604 \mathrm{~kg} \mathrm{ha}^{-1}$, respectively), crop phosphorus uptake $(52.71 \mathrm{~kg}$ $\left.\mathrm{ha}^{-1}\right)$, available soil $\mathrm{P}$ at crop harvest $\left(23.35 \mathrm{~kg} \mathrm{ha}^{-1}\right)$, gain in availablesoil $\mathrm{P}\left(3.21 \mathrm{~kg} \mathrm{ha}^{-1}\right)$ and dry biomass of residues (4649.1 $\mathrm{kg} \mathrm{ha}^{-1}$ ) and Precycled $\left(11.56 \mathrm{~kg} \mathrm{ha}^{-1}\right)$. Out of PGRs, BR + IAA recorded significantly higher pooled seed and stover yield (2922 and $12379 \mathrm{~kg}$ $\mathrm{ha}^{-1}$, respectively), crop phosphorus uptake $\left(47.12 \mathrm{~kg} \mathrm{ha}^{-1}\right)$, dry biomass of residues (4186.9 $\left.\mathrm{kg} \mathrm{ha}^{-1}\right)$ and Precycled $\left(10.44 \mathrm{~kg} \mathrm{ha}^{-1}\right)$.

\section{Introduction}

India annually imports edible oil worth about $>9$ million US \$ mainly due to poor oilseed productivity that arise out from severe imbalances in NPK use (current NPK removal34 Mt as against addition of $18 \mathrm{Mt}$ and current N: P: K consumption ratio 8.9: 2.8: 1.0 as against 4:2:1), climatic adversities (unfavourable temperatures, aberrant rains etc.) and physiological and genetic constraints associated with oilseeds (Hegde et al., 2012, 
Babu et al., 2014). Further, Indian agricultural soils have a negative annual $\mathrm{P}$ balance $(11 \mathrm{~kg}$ $\mathrm{P}_{2} \mathrm{O}_{5} \mathrm{ha}^{-1}$ ), severely disturbed $\mathrm{N}: \mathrm{P}_{2} \mathrm{O}_{5}: \mathrm{K}_{2} \mathrm{O}$ : $\mathrm{S}$ ratio (14.7:5.1:1.1:1.0), depleting state of soil organic matter and increasing instances of micro-nutrient deficiencies and yield stagnations which needs to be corrected for sustained oilseed productivity (Tandon, 2007, TSI, 2014). Indian mustard, the $2^{\text {nd }}$ largest oilseed crop in India, faces a cafeteria of production constraints but inadequate and imbalanced $\mathrm{P}$ fertilization and variable chemical precipitations of applied $\mathrm{P}$ are main hurdles in the way of sustained and higher productivity. Use of residues and manures and approach of feeding crop rather than soil, can improve crop $\mathrm{P}$ recoveries (Dawson and Hilton, 2011 Edward et al., 2015) but Indian agriculture primarily relies on chemical $\mathrm{P}$ fertilizers that provide $78 \%$ input when $\mathrm{P}$ removal by major crops is about $1.3 \mathrm{Mt}$ (Pathak et al., 2010). Residues devoid of any appreciable alleleopathic effect on some other or dominant crops in the region or rotation are suitable for recycling (Babu et al., 2014). Fortunately, alleleopathic effect of mustard residues is rare (Kalinova, 2010). Organic matter sorb applied $\mathrm{P}$ and increases its availability to plants due to competition between decomposition products of organic matter and $\mathrm{P}$ for soil sorption sites that increases labile $\mathrm{P}$ concentrations (Guppy et al., 2005). Residual $\mathrm{P}$ is better than fertilizer $\mathrm{P}$ provided a satisfactory critical soil $\mathrm{P}$ level (level 2) is maintained. Once this level is achieved, fertilizing each crop becomes not necessary and fertilizers can be applied at any point of rotation, broadcasted after crop is drilled rather than incorporated and 3 years crop $\mathrm{P}$ requirement can be supplemented in one application (Defra, 2010). As such, a serious thought and work on residue or organic matter agronomy is needed for making sustainable the Indian agriculture. Soils release 5-9 $\mathrm{kg} \mathrm{P}_{2} \mathrm{O}_{5} \mathrm{ha}^{-1}$ year $^{-1}$ without any use of fertilizer (Edwards et al., 2015), therefore, mobilizing large non available $\mathrm{P}$ through use of organic manures and biofertilizers by devising suitable integrated nutrient management (INM) modules can be a right answer to $\mathrm{P}$ related problems in India since $\mathrm{P}$ is the most reactive in soil system and it is very difficult to optimise its flows and fluxes within and off the farm (Dawson and Hilton, 2011). In this study, $P$ flows and fluxes within a field were grossly be estimated by simple mathematical calculations utilizing data on nutrient additions, crop nutrient removals, soil nutrient status before sowing and at crop harvest and estimation of unaccounted nutrient losses by preparation of nutrient balance sheets.

PGRs mitigate abiotic and biotic stresses by favourably influencing various physiological, metabolic, structural and other plant processes (Castle et al., 2003, Haubrick and Assmann, 2006, Biesaga et al., 2014). Indian mustard also faces high temperature stress at pod formation and grain filling stages in North West India. Also, crop is beset with several inherent physiological and genetic limitations (indeterminate growth, flower and bud drop, lodging, shattering etc.).However, comparative performance of PGRs on crop P recovery, sustainable yields and economic feasibility lacks widely in India. Integrated use of balanced nutrients and PGRs sustainably enhance yield and quality of crops through harmonizing various physiological processes like specific stimulation of harvestable organs and favourable source to sink relations by BR (Rathke et al., 2006). Favourable effects of BRs on growth and yield of different crops is widely studied and ascribed to diverse physiological processes and reasons (Haubrick and Assmann, 2006, Choudhary et al., 2012, Dobrikova et al., 2014). Auxins also favourably influence a variety of plant physiological processes and improve growth and yield of crops (Gadallah, 2000, Ali et al., 2007). Therefore, this 
research article is discussing the results on influence of different nutrient and PGR treatments on crop $\mathrm{P}$ recoveries, maintenance of available soil $\mathrm{P}$, residues and $\mathrm{P}$ recycling and yield of Indian mustard on medium clay loam soils of Udaipur.

\section{Materials and Methods}

A 2-year field study was conducted at Udaipur $\left(24^{0} 35^{\prime} \mathrm{N}\right.$ latitude and $73.42^{\prime} \mathrm{E}$ longitude) in Rajasthan state of India in agroclimatic zone IV a (Sub-Humid Southern Plains and Aravali Hills) at an elevation of $582.5 \mathrm{~m}$ above mean sea level during winters of 2012 and 2013. The experimental soil was well drained clay loam (sand: $38.20 \%$, silt: $25.70 \%$ and clay: $36.10 \%$ ) having an alkali $\mathrm{pH} 8.2$, bulk density $138 \mathrm{Mg} / \mathrm{m}^{3}$, soil organic carbon $0.66 \%$, field capacity $28.6 \%$, permanent wilting point $12.4 \%$ and available $\mathrm{N}, \mathrm{P}_{2} \mathrm{O}_{5}$ and $\mathrm{S}$ to a tune of $283.2,20.13$ and $33.26 \mathrm{~kg} \mathrm{ha}^{-1}$, respectively. Eight nutrient treatments $\left(\mathrm{N}_{1}: 75 \% \mathrm{RDF}, \mathrm{N}_{2}: 100 \% \mathrm{RDF}\right.$ or 60:35:40 kg N: $\mathrm{P}_{2} \mathrm{O}_{5}: \mathrm{S} \mathrm{ha}^{-1}$, respectively, $\mathrm{N}_{3}$ : $\mathrm{N}_{1}+5$ t FYM ha $^{-1}, \mathrm{~N}_{4}: \mathrm{N}_{2}+5$ t FYM ha $^{-1}, \mathrm{~N}_{5}$ : $\mathrm{N}_{1}+$ Azotobacter + PSB or bio-fertilizers, $\mathrm{N}_{6}$ : $\mathrm{N}_{2}+$ bio-fertilizers, $\mathrm{N}_{7}: \mathrm{N}_{3}+$ bio-fertilizers and $\mathrm{N}_{8}: \mathrm{N}_{4}+$ bio-fertilizers) in main plots and four PGRs $\left(\mathrm{G}_{0}\right.$ : Control, $\mathrm{G}_{1}$ : BR $0.5 \mathrm{ppm}, \mathrm{G}_{2}$ : IAA 50 ppm and $\mathrm{G}_{3}$ : BR $0.5 \mathrm{ppm}+$ IAA 50 ppm) in sub plots were evaluated in a split plot design replicated thrice. Gross sub plot $(5.0 \times 3.6 \mathrm{~m})$ were reduced to $4.0 \times 2.4 \mathrm{~m}$ for estimation of yield and deriving soil samples at crop harvested on turning uniform pale in colour after removal of border rows. Certified seed of Indian mustard (Cv. Laxmi) was drilled in rows at $30 \mathrm{~cm}$ on 24.10.2012 and 26.10.2013 in a field under continuous maize crop for previous five rainy seasons. A plant to plant spacing of $10 \mathrm{~cm}$ was manually maintained within the each row while carrying out the hoeing and weeding at 20 days crop stage. Full quantity of well rotten FYM, bio-fertilizers (Azotobacter and PSB each@600 g culture ha ${ }^{-1}$ ), phosphorus and gypsum and half quantity of $\mathrm{N}$ were carefully applied as basal dressing in each main and sub plot after weighing on a highly precise digital electronic balance (accuracy: $0.01 \mathrm{~g}$ ) through a close band placement in the side of seed furrow strictly following the treatment specifications. Remaining half $\mathrm{N}$ was topdressed in two equal splits at 38 and 78 days crop stages i.e. about three days after $1^{\text {st }}$ and $2^{\text {nd }}$ irrigation (each about $6 \mathrm{~cm}$ depth), respectively. BR $0.5 \mathrm{ppm}$ was prepared from $400 \mathrm{ppm}$ stock solution throrugh pouring and thoroughly mixing $1 \mathrm{ml}$ stock solution in 800 ml water whereas $98 \%$ pure IAA crystals were used as stock material to prepare $50 \mathrm{ppm}$ solution by dissolving $1 \mathrm{~g}$ of original stock material in 19.6 litre water. Foliar spray of both BR and IAA was carried out seperately one after another (not tank mixed) at a very close time interval of about 5 minutes twice at 30 and 60 days crop stages using 500 litre spray volume $\mathrm{ha}^{-1}$ at each instance and carefully ensuring an uniform foliage wetting. Pcontentin oven dried FYM, mustard seed and stover and composite samples of crop and weed roots, litterfall and above ground weed biomass was estimated by ammonium vanadomolybdate yellow colour method (Richards, 1968). Oven dried FYM contained $0.23 \%$ P. Roots of crop and weeds were collected carefully at two points in each sub plot by digging a $100 \mathrm{~cm}$ long, $30 \mathrm{~cm}$ wide (keeping mustard row in centre) and $15 \mathrm{~cm}$ deep pits and carefully sorting the roots from loose soil. Above ground weed biomass was collected by manually and harvesting all weeds close to ground with sickle on an area $0.3 \mathrm{M}^{2}$ (one meter strip having the mustard row in centre). Litter fall (leaves, twigs, flower petals etc.) during 45 days stage to maturity, was collected by spreading a $100 \mathrm{x}$ $30 \mathrm{~cm}$ wide polythene strip at two points in inter row space of mustard and fixing the corners and centre of sheets using 1.5" iron nails in each sub plot. $\mathrm{P}$ content in plant 
samples were determined after oven drying at $65^{\circ} \mathrm{C}$ till a constant weight was achieved and grinding the material to required fineness. $\mathrm{P}$ concentration in residues recycled at harvest of mustard crop viz. dry roots $(0.238 \%)$, litter fall $(0.26 \%)$ and weed biomass $(0.47 \%)$ was determined through compositing respective plant samples from all the sub plots in one replication. $\mathrm{P}$ uptake by mustard seed and stover, crop and weed roots, litterfall and above ground weed biomass were calculated by multiplying nutrient content with corresponding dry biomass and converting them in $\mathrm{kg} \mathrm{ha}^{-1}$. Soil samples randomly collected by augur from furrow slice (0-15 $\mathrm{cm})$ zone at three random points in each sub plot were thoroughly mixed and finally $100 \mathrm{~g}$ soil was carefully derived following repeated half accept and half reject method. Available soil phosphorus before sowing and at crop harvest was determined by Olsen method (Olsen et al., 1954). Nutrient balance sheets were prepared on the basis of initial nutrient status, nutrients added, soil nutrient status at crop harvest, total crop nutrient uptake and calculation of unaccounted nutrient losses. Data were statistically analysed during each year of study and on pooled basis deploying standard procedure for analysis of variance (ANOVA) of split plot design (Gomez and Gomez, 1984).

\section{Results and Discussion}

\section{Available P balance}

Pooled crop $\mathrm{P}$ uptake ( $\mathrm{C}$ values) registered a significant variation among PGRs (BR + IAA $>\mathrm{BR}>\mathrm{IAA}>$ water spray). Integration of either 75 or $100 \%$ RDF with FYM + biofertilizers, FYM and bio-fertilizers also registered significant variations in pooled $\mathrm{C}$ values but differences between $\mathrm{N}_{2}$ and $\mathrm{N}_{6}$ were at par (Table 1). Pooled $\mathrm{C}$ values ranging from $34.46\left(\mathrm{~N}_{1}\right)$ to $52.71 \mathrm{~kg} \mathrm{ha}^{-1}\left(\mathrm{~N}_{8}\right)$ and 38.43 (water spray) to $47.12 \mathrm{~kg} \mathrm{ha}^{-1}(\mathrm{BR}+$
IAA) variably exceeded the corresponding B values depicting an additional $\mathrm{P}$ mining over and above the applied $\mathrm{P}$ to an extent of 5.30 $\left(\mathrm{N}_{4}\right)$ to $17.34 \mathrm{~kg} \mathrm{ha}^{-1}\left(\mathrm{~N}_{8}\right)$ and 7.68 (water spray) to $16.37 \mathrm{~kg} \mathrm{ha}^{-1}(\mathrm{BR}+\mathrm{IAA})$. Analysis of pooled $\mathrm{C}$ values as a fraction of pooled $\mathrm{A}+$ $\mathrm{B}$ values shows that crop $\mathrm{P}$ recovery ranged from $73.93 \%\left(\mathrm{~N}_{1}\right)$ to $89.81 \%\left(\mathrm{~N}_{8}\right)$ and 75.69 (water spray) to $92.52 \%$ (BR + IAA) which is exceptionally high against usual crop $P$ recovery $(35-50 \%)$. This pin points on a cafeteria of possible routes potent to strengthen the available $\mathrm{P}$ pool viz. $\mathrm{P}$ mineralization from recycled residues at harvest of previous maize crop, $\mathrm{P}$ release from non-labile pool, $\mathrm{P}$ benefits from PSB, crop $\mathrm{P}$ mining from beneath the furrow slice etc. or there can be a higher recovery of applied $\mathrm{P}$ due to band placement of $\mathrm{P}$ fertilizer close to seed furrow along with gypsum.

Higher crop $\mathrm{P}$ recovery due to presence of $\mathrm{S}$ traces (10-12\%) in single super phosphate has also been reported by Khaswa et al., 2014in soybean in Udaipur region. Also, a large quantity of weed residues is recycled at maize harvest in Udaipur region (Chalka and Nepalia, 2005).In this study, simultaneous band placement of both $\mathrm{P}$ and $\mathrm{S}$ fertilizer can largely reduce the contact surface between reactive mineral and fertilizer $\mathrm{P}$ and can increase $\mathrm{H}_{2} \mathrm{PO}_{4}{ }^{-}$adsorption on exchange sites and prevent chemical precipitation of $\mathrm{H}_{2} \mathrm{PO}_{4}{ }^{-}$ ions/applied $\mathrm{P}$ as $\mathrm{Ca}-\mathrm{P}$ complexes. Total soil $\mathrm{P}$ is usually low $(10-25 \%$ of $\mathrm{N}$ and $5 \%$ of $\mathrm{K}$ ) and can range between 200 to $2000 \mathrm{~kg} \mathrm{ha}^{-1}$ in furrow slice (average: about $1000 \mathrm{~kg} \mathrm{ha}^{-1}$ ) (Jones and Eva, 2011). This is notable that a fairly high quantity of $\mathrm{P}$ was contained in total residues (Table 3 ) recycled at harvest of even a winter seasons mothering crop like mustard normally beset with a sparse weed infestation and weed biomass per unit area than a highly weedy rainy season maize crop. This indicates a huge residue and large $\mathrm{P}$ 
recycling potent to benefit mustard crop after growing maize. Organic compounds in soil increase $\mathrm{P}$ availability to plants due to formation of organophosphate complexes, replacement of $\mathrm{H}_{2} \mathrm{PO}_{4}$ ions on adsorption sites by other anions and more mineralized organic $\mathrm{P}$ relative to inorganic $\mathrm{P}$ (Gyneswar et al., 2002). Available $P$ is normally a resultant of physico-chemical (sorption-desorption) and biological (mineralization-immobilization) processes and a large fraction of fertilizer $\mathrm{P}$ can enter into non available pool via chemical reaction with highly reactive $\mathrm{Al}^{+}$and $\mathrm{Fe}^{3+}$ in acidic soils while with $\mathrm{Ca}^{2+}$ in calcareous and normal soils (Hao et al., 2002). Concentration of bio-available soil $\mathrm{P}$ is very low $\left(1 \mathrm{mg} \mathrm{kg}^{-1}\right.$ soil) but PSB can potentially enhance $P$ availability to crop plants through mineralization of organic $\mathrm{P}$ and dissolution of precipitated $\mathrm{P}$ through release of organic acids and assimilation of labile $\mathrm{P}$ in microbial biomass which prevents $\mathrm{P}$ from being adsorbed/fixed (Richardson, 2001, Chen et $a l .$, 2006).

In fact, $\mathrm{P}$ adsorption is more in soils having less $\mathrm{P}$ adsorbed on mineral micelle in want of full saturation of exchange sites. Clay loam soils of Udaipur have medium state of available $\mathrm{P}$ which at the most exhibit an intermediate $\mathrm{P}$ adsorption but this too can enable a fairly high recovery of fertilizer $\mathrm{P}$ under continuous sorption-desorption process. Organic P can move to a more depth through soil solution in comparison to inorganic $\mathrm{P}$ that is why continued manures use leads to soil $\mathrm{P}$ build-up even up to $60-120 \mathrm{~cm}$ depth while use of same quantity of $\mathrm{P}$ through fertilizers shows less downward movement of $\mathrm{H}_{2} \mathrm{PO}_{4}$ ions, however these ions can be well intercepted by deep rooted mustard plants. Further, microbial organic $\mathrm{P}$ mineralization in presence of phosphatase enzyme can constitute about $50 \%$ part of available $\mathrm{P}$ (range: 15-80\%). Available $\mathrm{P}$ increases with enhancing soil organic $\mathrm{P}$ level but inorganic $\mathrm{P}$ immobilized is inversely related to organic $\mathrm{P}$ and increases when C: P ratio exceeds 200. Thus, FYM/recycled residues can appreciably influence available $\mathrm{P}$ levels in this study. Organic anions (citrate, oxalate, tartrate and malate) can be adsorbed on exchange complex and replace adsorbed $\mathrm{H}_{2} \mathrm{PO}_{4}{ }^{-}$in labile pool, thus adsorbed $\mathrm{P}$ is reduced and available $\mathrm{P}$ is enhanced. However availability of organic anions depends on soil organic matter (SOM) level while Udaipur soils have medium SOM category. It is established that $>0.3 \% \mathrm{P}$ content in residues favours net $\mathrm{P}$ mineralization and immobilization dominates if residues contain $<0.2 \% \mathrm{P}$ (Havlin et al., 2007). It is already mentioned in materials and method part that FYM and other residues recycled at mustard harvest contained $\mathrm{P}$ in the range of $0.22-0.48 \%$ which forms a strong basis for high $\mathrm{P}$ mineralization from previous crop/weed residues.

Mineralization of organic $\mathrm{P}$ can be further supported by bright sunny days and moderate winter temperature during mustard crop period in Udaipur region while high temperature encourages adsorption of $\mathrm{H}_{2} \mathrm{PO}_{4}{ }^{-}$ ions on mineral micelle. Though $\mathrm{P}$ immobilization from applied fertilizer vary widely (25-100\%) but as a rule continued $\mathrm{P}$ fertilization which is a practice in NW India can increases soil organic $\mathrm{P}$ content.

There is favourable effect of PGRs on root growth (Bao et al., 2004) which appears to be one of the prime reasons behind significant variations in pooled $\mathrm{C}$ values among different PGRs. Pooled $\mathrm{C}$ values significantly increased with increase in RDF from $75 \%$ to $100 \%$ which was 39.81 and $45.31 \mathrm{~kg} \mathrm{ha}^{-1}$ (average of set of four treatments in each RDF level), respectively. Significantly higher pooled $\mathrm{C}$ values in $\mathrm{N}_{8}$ can also be ascribed to a synergistic interaction between FYM and bio-fertilizers (Chand and Ram, 2008). These dispositions well support the high $\mathrm{P}$ recovery by Indian mustard under different nutrient and PGR treatments in this study. 
Table.1 Available P balance sheet $\left(\mathrm{kg} \mathrm{ha}^{-1}\right)$ under different nutrient and PGR treatments in Indian mustard

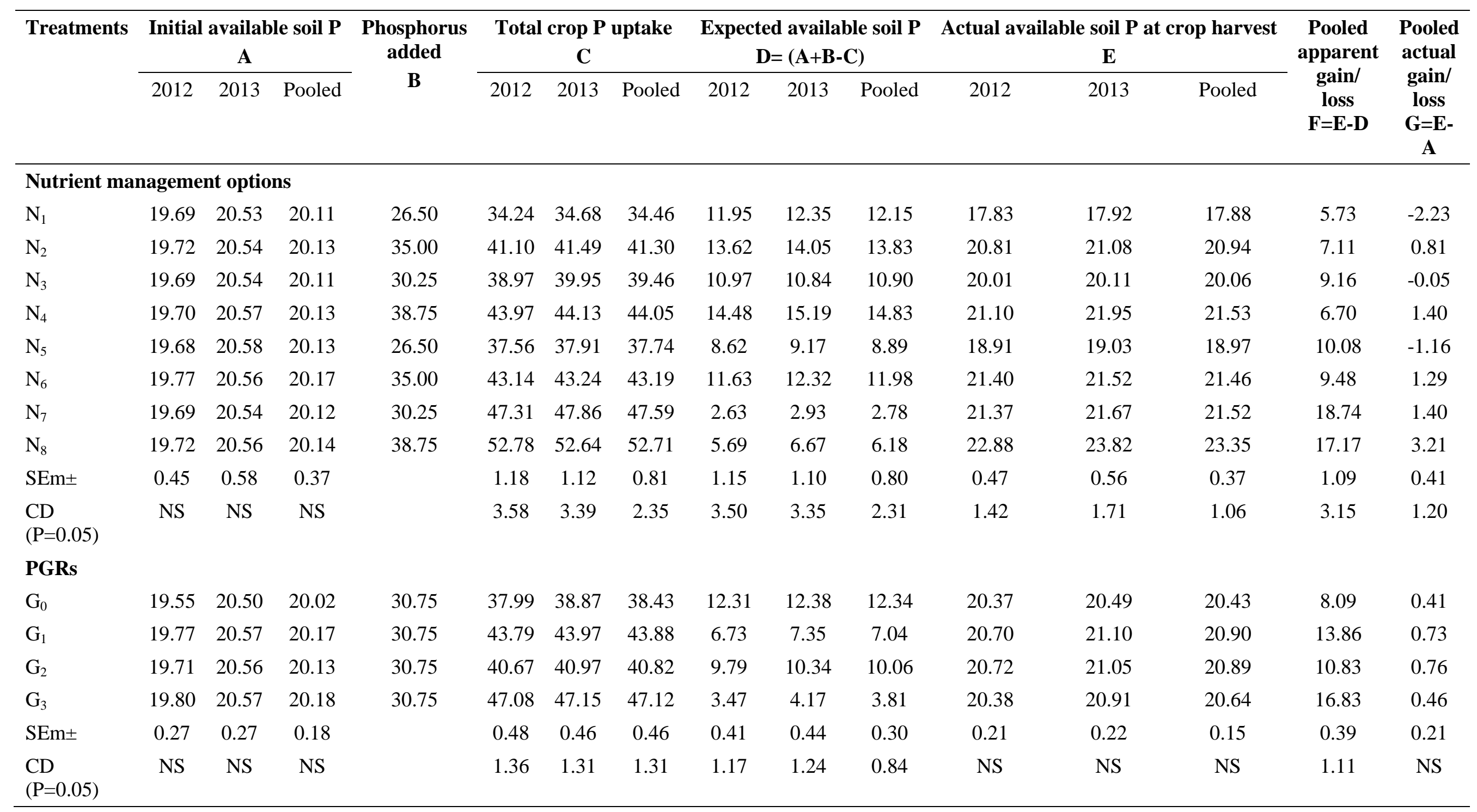


Table. 2 Dry biomass of litter fall, weeds, roots and total residues $\left(\mathrm{kg} \mathrm{ha}^{-1}\right)$ recycled under different nutrient and PGR treatmentsat mustard harvest

\begin{tabular}{|c|c|c|c|c|c|c|c|c|c|c|c|c|}
\hline \multirow[t]{2}{*}{ Treatments } & \multicolumn{3}{|c|}{ Litter fall } & \multicolumn{3}{|c|}{ Weed biomass } & \multicolumn{3}{|c|}{ Dry roots } & \multicolumn{3}{|c|}{ Total residues } \\
\hline & 2012 & 2013 & Pooled & 2012 & 2013 & Pooled & 2012 & 2013 & Pooled & 2012 & 2013 & Pooled \\
\hline \multicolumn{13}{|c|}{ Nutrient management options } \\
\hline $\mathrm{N}_{1}$ & 926.1 & 920.2 & 923.1 & 142.7 & 142.9 & 142.8 & 2387.0 & 2413.0 & 2400.0 & 3455.8 & 3476.1 & 3465.9 \\
\hline $\mathrm{N}_{2}$ & 969.3 & 969.5 & 969.4 & 127.4 & 126.9 & 127.2 & 2686.1 & 2709.2 & 2697.7 & 3782.8 & 3805.6 & 3794.2 \\
\hline $\mathrm{N}_{3}$ & 1083.1 & 1077.9 & 1080.5 & 132.9 & 133.0 & 132.9 & 2624.8 & 2665.0 & 2644.9 & 3840.9 & 3875.9 & 3858.4 \\
\hline $\mathrm{N}_{4}$ & 1120.6 & 1113.6 & 1117.1 & 121.7 & 121.7 & 121.7 & 2900.8 & 2926.6 & 2913.7 & 4143.1 & 4161.9 & 4152.5 \\
\hline $\mathrm{N}_{5}$ & 1121.8 & 1119.5 & 1120.7 & 138.6 & 138.4 & 138.5 & 2569.0 & 2591.4 & 2580.2 & 3829.3 & 3849.3 & 3839.3 \\
\hline $\mathrm{N}_{6}$ & 1178.1 & 1174.0 & 1176.0 & 126.5 & 126.4 & 126.4 & 2843.3 & 2862.7 & 2853.0 & 4147.9 & 4163.1 & 4155.5 \\
\hline $\mathrm{N}_{7}$ & 1384.7 & 1411.5 & 1398.1 & 124.7 & 124.8 & 124.7 & 2778.3 & 2800.9 & 2789.6 & 4287.6 & 4337.2 & 4312.4 \\
\hline $\mathrm{N}_{8}$ & 1426.2 & 1467.9 & 1447.0 & 115.0 & 114.4 & 114.7 & 3006.1 & 3108.5 & 3057.3 & 4547.3 & 4690.9 & 4619.1 \\
\hline $\mathrm{SEm} \pm$ & 12.6 & 19.9 & 11.8 & 5.3 & 5.1 & 3.7 & 65.9 & 73.1 & 49.2 & 67.2 & 85.7 & 54.4 \\
\hline $\mathrm{CD}(\mathrm{P}=0.05)$ & 38.3 & 60.2 & 34.1 & 16.2 & 15.4 & 10.7 & 200.0 & 221.9 & 142.6 & 203.7 & 260.0 & 157.7 \\
\hline \multicolumn{13}{|l|}{ PGRs } \\
\hline $\mathrm{G}_{0}$ & 1343.5 & 1347.0 & 1345.2 & 137.4 & 137.6 & 137.5 & 2423.0 & 2467.2 & 2445.1 & 3903.8 & 3951.8 & 3927.8 \\
\hline $\mathrm{G}_{1}$ & 1073.4 & 1072.3 & 1072.8 & 126.9 & 126.7 & 126.8 & 2741.4 & 2771.5 & 2756.5 & 3941.7 & 3970.6 & 3956.1 \\
\hline $\mathrm{G}_{2}$ & 1265.9 & 1258.6 & 1262.2 & 129.1 & 128.7 & 128.9 & 2622.5 & 2650.9 & 2636.7 & 4017.5 & 4038.2 & 4027.9 \\
\hline $\mathrm{G}_{3}$ & 922.1 & 949.2 & 935.7 & 121.3 & 121.2 & 121.3 & 3110.9 & 3149.0 & 3129.9 & 4154.3 & 4219.5 & 4186.9 \\
\hline $\mathrm{SEm} \pm$ & 8.4 & 10.4 & 6.7 & 3.7 & 2.8 & 2.3 & 35.6 & 37.5 & 25.9 & 37.3 & 40.9 & 27.7 \\
\hline $\mathrm{CD}(\mathrm{P}=0.05)$ & 24.0 & 29.6 & 18.8 & 10.4 & 7.9 & 6.4 & 101.2 & 106.7 & 72.6 & 106.2 & 116.3 & 77.8 \\
\hline
\end{tabular}


Table.3 Pcontained in dry roots, litter fall, weed biomass and various residues $\left(\mathrm{kg} \mathrm{ha}^{-1}\right)$ under different nutrient and PGR treatmentsat mustard harvest

\begin{tabular}{|c|c|c|c|c|c|c|c|c|c|c|c|c|}
\hline \multirow[t]{2}{*}{ Treatments } & \multicolumn{3}{|c|}{ Roots } & \multicolumn{3}{|c|}{ Litter fall } & \multicolumn{3}{|c|}{ Weeds } & \multicolumn{3}{|c|}{ Total residues } \\
\hline & 2012 & 2013 & Pooled & 2012 & 2013 & Pooled & 2012 & 2013 & Pooled & 2012 & 2013 & Pooled \\
\hline \multicolumn{13}{|c|}{ Nutrient management options } \\
\hline $\mathrm{N}_{1}$ & 5.73 & 5.67 & 5.70 & 2.41 & 2.39 & 2.40 & 0.68 & 0.66 & 0.67 & 8.82 & 8.72 & 8.77 \\
\hline $\mathrm{N}_{2}$ & 6.45 & 6.37 & 6.41 & 2.52 & 2.52 & 2.52 & 0.61 & 0.58 & 0.60 & 9.58 & 9.47 & 9.52 \\
\hline $\mathrm{N}_{3}$ & 6.30 & 6.26 & 6.28 & 2.82 & 2.80 & 2.81 & 0.64 & 0.61 & 0.62 & 9.75 & 9.68 & 9.72 \\
\hline $\mathrm{N}_{4}$ & 6.96 & 6.88 & 6.92 & 2.91 & 2.90 & 2.90 & 0.58 & 0.56 & 0.57 & 10.46 & 10.33 & 10.40 \\
\hline $\mathrm{N}_{5}$ & 6.17 & 6.09 & 6.13 & 2.92 & 2.91 & 2.91 & 0.67 & 0.64 & 0.65 & 9.75 & 9.64 & 9.69 \\
\hline $\mathrm{N}_{6}$ & 6.82 & 6.73 & 6.78 & 3.06 & 3.05 & 3.06 & 0.61 & 0.58 & 0.59 & 10.49 & 10.36 & 10.43 \\
\hline $\mathrm{N}_{7}$ & 6.67 & 6.58 & 6.62 & 3.60 & 3.67 & 3.64 & 0.60 & 0.57 & 0.59 & 10.87 & 10.83 & 10.85 \\
\hline $\mathrm{N}_{8}$ & 7.21 & 7.30 & 7.26 & 3.71 & 3.82 & 3.76 & 0.55 & 0.53 & 0.54 & 11.47 & 11.65 & 11.56 \\
\hline SEm \pm & 0.16 & 0.17 & 0.12 & 0.03 & 0.05 & 0.03 & 0.03 & 0.02 & 0.02 & 0.17 & 0.21 & 0.14 \\
\hline $\mathrm{CD}(\mathrm{P}=0.05)$ & 0.48 & 0.52 & 0.34 & 0.10 & 0.16 & 0.09 & 0.08 & 0.06 & 0.05 & 0.52 & 0.64 & 0.39 \\
\hline \multicolumn{13}{|l|}{ PGRs } \\
\hline $\mathrm{G}_{0}$ & 5.82 & 5.80 & 5.81 & 3.49 & 3.50 & 3.50 & 0.66 & 0.63 & 0.65 & 9.97 & 9.93 & 9.95 \\
\hline $\mathrm{G}_{1}$ & 6.58 & 6.51 & 6.55 & 2.79 & 2.79 & 2.79 & 0.61 & 0.58 & 0.60 & 9.98 & 9.88 & 9.93 \\
\hline $\mathrm{G}_{2}$ & 6.29 & 6.23 & 6.26 & 3.29 & 3.27 & 3.28 & 0.62 & 0.59 & 0.61 & 10.21 & 10.09 & 10.15 \\
\hline $\mathrm{G}_{3}$ & 7.47 & 7.40 & 7.43 & 2.40 & 2.47 & 2.43 & 0.58 & 0.56 & 0.57 & 10.45 & 10.43 & 10.44 \\
\hline SEm \pm & 0.09 & 0.09 & 0.06 & 0.02 & 0.03 & 0.02 & 0.02 & 0.01 & 0.01 & 0.09 & 0.10 & 0.07 \\
\hline $\mathrm{CD}(\mathrm{P}=0.05)$ & 0.24 & 0.25 & 0.17 & 0.06 & 0.08 & 0.05 & 0.05 & 0.04 & 0.03 & 0.27 & 0.28 & 0.19 \\
\hline
\end{tabular}


Int.J.Curr.Microbiol.App.Sci (2017) 6(8): 3319-3331

Table.4 Seed and stover yield $\left(\mathrm{kg} \mathrm{ha}^{-1}\right)$ of Indian mustard under different nutrient and PGR treatments

\begin{tabular}{|c|c|c|c|c|c|c|}
\hline \multirow[t]{2}{*}{ Treatments } & \multicolumn{3}{|c|}{ Seed yield } & \multicolumn{3}{|c|}{ Stover yield } \\
\hline & 2012 & 2013 & Pooled & 2012 & 2013 & Pooled \\
\hline \multicolumn{7}{|c|}{ Nutrient management options } \\
\hline $\mathrm{N}_{1}$ & 2236 & 2270 & 2253 & 9650 & 9801 & 9726 \\
\hline $\mathrm{N}_{2}$ & 2601 & 2640 & 2621 & 11054 & 11198 & 11126 \\
\hline $\mathrm{N}_{3}$ & 2500 & 2541 & 2521 & 10764 & 10909 & 10836 \\
\hline $\mathrm{N}_{4}$ & 2762 & 2787 & 2774 & 11668 & 11750 & 11709 \\
\hline $\mathrm{N}_{5}$ & 2384 & 2438 & 2411 & 10406 & 10486 & 10446 \\
\hline $\mathrm{N}_{6}$ & 2707 & 2733 & 2720 & 11492 & 11540 & 11516 \\
\hline $\mathrm{N}_{7}$ & 2930 & 2977 & 2953 & 12505 & 12690 & 12598 \\
\hline $\mathrm{N}_{8}$ & 3228 & 3235 & 3231 & 13606 & 13602 & 13604 \\
\hline SEm \pm & 065 & 063 & 045 & 287 & 274 & 198 \\
\hline $\mathrm{CD}(\mathrm{P}=0.05)$ & 198 & 190 & 131 & 869 & 831 & 574 \\
\hline \multicolumn{7}{|l|}{ PGRs } \\
\hline $\mathrm{G}_{0}$ & 2452 & 2503 & 2478 & 10509 & 10705 & 10607 \\
\hline $\mathrm{G}_{1}$ & 2733 & 2763 & 2748 & 11647 & 11750 & 11698 \\
\hline $\mathrm{G}_{2}$ & 2582 & 2607 & 2595 & 11091 & 11102 & 11097 \\
\hline $\mathrm{G}_{3}$ & 2907 & 2937 & 2922 & 12326 & 12432 & 12379 \\
\hline SEm \pm & 026 & 028 & 019 & 122 & 129 & 089 \\
\hline $\mathrm{CD}(\mathrm{P}=0.05)$ & 075 & 081 & 054 & 346 & 366 & 249 \\
\hline
\end{tabular}


Lower pooled $\mathrm{E}$ values than corresponding pooled A values indicate over mining of available $\mathrm{P}$ in furrow slice, however, higher pooled $\mathrm{E}$ values over corresponding expected pooled $\mathrm{D}$ values indicate variable $\mathrm{P}$ build up in furrow slice under different nutrient and PGR treatments against the depletion that was theoretically expected. Pooled $\mathrm{F}$ values ranged from $5.73\left(\mathrm{~N}_{1}\right)$ to $18.74 \mathrm{~kg} \mathrm{ha}^{-1}\left(\mathrm{~N}_{7}\right)$ and 8.09 (water spray) to $16.83 \mathrm{~kg} \mathrm{ha}^{-1}(\mathrm{BR}+$ IAA). Analysis of pooled $\mathrm{F}$ values also indicate significantly lower crop $\mathrm{P}$ mining in nutrient treatments involving 75\% $\left(\mathrm{N}_{1}, \mathrm{~N}_{3}\right.$, $\mathrm{N}_{5}, \mathrm{~N}_{7}$ ) than their corresponding counter parts having $100 \% \operatorname{RDF}\left(\mathrm{N}_{2}, \mathrm{~N}_{4}, \mathrm{~N}_{6}, \mathrm{~N}_{8}\right)$ together with lesser depletion in available $\mathrm{P}$ levels in latter set of treatments. This can be ascribed to significant variations in pooled seed and stover yield between nutrient treatments having 75 and 100\% RDF (Table 4). All nutrient and PGR treatments involving $100 \%$ RDF recorded a positive pooled $G$ value (range: 0.81 in $\mathrm{N}_{2}$ to $3.21 \mathrm{~kg} \mathrm{ha}^{-1}$ in $\mathrm{N}_{8}$ and 0.41 in water spray to $0.76 \mathrm{~kg} \mathrm{ha}^{-1}$ in IAA) but variations among PGRs was not significant. Data on pooled actual gain/loss in available $P$ ( $G$ values) reveal that 3 out of 4 nutrient treatments involving $75 \% \operatorname{RDF}\left(\mathrm{N}_{1}, \mathrm{~N}_{3}, \mathrm{~N}_{5}\right)$ recorded negative values while $\mathrm{N}_{7}$ registered a positive value. Build up in pooled available $\mathrm{P}$ as revealed by positive $\mathrm{G}$ values under $\mathrm{N}_{7}$ and nutrient treatments involving $100 \% \mathrm{RDF}$ indicate relative sufficiency of available $\mathrm{P}$ under these treatments and other dispositions enumerated earlier.

\section{Recycling of residues and $P$}

Among nutrient and PGR treatments, $\mathrm{N}_{8}$ and $\mathrm{BR}+\mathrm{IAA}$ recorded significantly higher pooled residues and $\mathrm{P}$ contained in root biomass, litter fall and total residues (Table 2 and 3) which can be ascribed to significantly higher growth which is otherwise indirectly endorsed by significantly higher seed and stover yield (Table 4). More senescence of plant organs under more growth that leads to more mutual shading are established facts. $\mathrm{N}_{1}$ recorded significantly higher pooled residues and $\mathrm{P}$ recycled through weed biomass but variations were at par among $\mathrm{N}_{1}, \mathrm{~N}_{5}$ and $\mathrm{N}_{7}$. This can be ascribed to significantly lower growth under these treatments as also indirectly indicated by seed and stover yield (Table 4) and lower smothering effect of crop plants on weed growth.

Different PGRs registered significant variations in pooled quantities of dry residues and $\mathrm{P}$ recycled through root biomass, litter fall and weed biomass (Table 2). Variations in pooled dry root biomass and $P$ recycled followed an order $\mathrm{BR}+\mathrm{IAA}>\mathrm{BR}>\mathrm{IAA}>$ water spray while variations in pooled litter fall and $\mathrm{P}$ recycled registered a reverse trend (water spray> IAA > BR> BR + IAA) on account of variations in growth, smothering effect on weeds and delay in senescence of plant organs under PGRs.

\section{Yield performance}

Significantly higher pooled seed and stover yield under $\mathrm{N}_{8}$ over other nutrient treatments (Table 4) can be ascribed to not only significantly higher pooled crop $\mathrm{P}$ uptake but also to more availability and uptake of other nutrients on account of $\mathrm{P}$ benefits from FYM, bio-fertilizers, synergistic interaction between FYM and bio-fertilizers etc. (Aulakh, 2010). Variations in pooled yield levels was identical to pooled crop $\mathrm{P}$ uptake but a response exceeding 100\% RDF (60:35:40 kg N: P: S $\mathrm{ha}^{-1}$ ) was noticed which is also well reported in other/.new mustard cultivars/agro-climatic zones in India. Role of $\mathrm{P}$ in significantly improving growth and yield of crops up to an optimum fertilizer level is well established but $\mathrm{P}$ is also involved in energy transformations, bio-chemical reactions apart from being a constituent of genetic material (Havlin et al., 2007). 
PGRs significantly influenced pooled yield levels $(\mathrm{BR}+\mathrm{IAA}>\mathrm{BR}>\mathrm{IAA}>$ water spray) on account of variations in their functions and influences. Owing to indeterminate growth habit of mustard plants, vegetative and reproductive phases compete with each another in want of metabolites, nutrients, water etc. Significantly higher pooled yield performance under $\mathrm{BR}+$ IAA relates to a strong synergistic interaction where auxin level controls endogenous level of BR and vice versa besides, a considerable cross talk/multi-level interaction that critically controls and profoundly promotes cell division, vascular bundle formation and synthesis of different bio-molecules (chlorophyll, monosaccharide, proteins etc.); promotion of lateral root growth and control of metabolism (Halliday, 2004, Bao et al., 2006, Bajguz and Niczyporuk, 2013). Superiority of BR over IAA links to a diverse variety of plant processes that this steroidal lactone regulates viz. transcription and translation, membrane stability, osmosis, stomatal conductance, control of plant processes at enzyme level, maintenance of optimum hormonal balance and $\mathrm{H}^{+}$pump activation, stimulation of cell enlargement, cell division, anti-oxidative enzymes (catalase, peroxidase, superoxide dismutase, tocophenols, trocophenols, trocotrienols, ascorbic acid, beta carotein etc.), biosynthesis of cell wall, chlorophyll, vascular bundle differentiation, pollen tube growth, microtubular organization, transport of assimilates from one part to another etc. These functions of BR improve anti-oxidative defence system of plants and enhance bio-synthesis of total proteins, nucleic acid, photosynthesis that finally growth and yield of plants (Haubrick and Assmann, 2006, Hayat, 2010 and Hola, 2011, Biesaga et al., 2014). BR is superior to IAA in significantly effecting higher growth and yield of Indian mustard due to higher chlorophyll content, photosynthetic rate and carbonic anhydrase activity (Hayat et al.,
2001). Auxins synthesized in meristematic cells of roots and shoot moves basipettally and regulate apical bud dominance, cell elongation and enlargement, cell wall biosynthesis, xylem differentiation and mRNA synthesis. Foliar usage of IAA enhances the growth and productivity of crop plants over water spray (Gadallah, 2000, Ali et al., 2007).

\section{Acknowledgement}

The authors are thankful to Department of Agronomy, Rajasthan College of Agriculture, Maharana Pratap University of Agriculture and Technology, Udaipur for providing necessary facilities in $\mathrm{Ph}$. D. work. We are also thankful to Research Scientist, Indian Institute of Soil and Water Conservation, Research centre, Chhalesar, Agra for the continuous support and encouragement during the course of investigation.

\section{References}

Ali, B., Hasan, S.A., Hayat, S. and Ahmad, A. 2007. Effects of two natural forms of auxins (IAA and 4-Cl-IAA) on photosynthesis, enzyme activities and ethylene production in mung bean (Vigna radiata L. Wilczek) plants. J. Plant Biol. 34:29-33.

Aulakh, M.S., 2010. Integrated nutrient management for sustainable crop production, improving crop quality and soil health and minimizing environmental pollution. In: proceeding of. $19^{\text {th }}$ World Congress of Soil Science, Soil Solutions for Changing World, 1-6 August, 2010. Brisbane, Australia, Published on DVD.

Babu, Subhash, Rana, D.S., Yadav, G.S. and Singh, Raghvendra. 2014. A review on recycling of sunflower residue for sustaining the soil health. International $J$. Agron., $\quad$ http/drdoi.org/10.1155/2014 /1049

Bajguz, A. P., and Niczyporuk, A. 2013. Synergistic effect of auxins and 
brassinosteroids on the growth and regulation of metabolite content in the green algae Chlorella vulgaris. Plant Physiol. \&Biochem. 71:290-297.

Bao, F., Shen, J.J., Brady, S.R., Muday, G.K., Asami, T. and Yang, Z.B. 2004. Brassinosteroids interact with auxin to promote lateral root development in Arabidopsis. Plant Physiol., 134:16241631.

Biesaga, K. J., Dziurka, M., Ostrowska, A., Mirek, M., Koscielniak, J., Janeczko, A. 2014. BR improves content of antioxidants in seed of selected leguminous plants. Austr. J. Crop Sci. 8:378-388.

Castle, J., Montoya, T. and Bishop, G.J. 2003. Selected physiological responses of BR: a historical approach. In: S. Hayat and A. Ahmad (Eds.) BR. Bioactivity and Crop Productivity. Kluwer Academic Publishers, Dordrecht-Boston-London. p. 45-68.

Chalka, M.K., and Nepalia, V. 2005. Production potential and economics of maize (Zea mays) as influenced by weed control. Indian Journal of Agronomy.50:119-122.

Chand, S., and Ram, D. 2008. PSM and Azotobacter population in rhizosphere soil of mustard as influenced by organic and inorganic sources. Environ. \& Ecol. 26:43-46.

Chen, Y.P., Rekha, P.D., Arunshen, A.B., Lai, W.A. andYoung, C.C. 2006. Phosphate solubilizing bacteria from subtropical soil and their tri-calcium phosphate solubilising abilities Appl.Soil Ecol. 34:33-41.

Choudhary, S.P., Yu, J.Q., Yamaguchi, Shinozaki, K., Shinozaki, Kand Lam, S. P.T. 2012. Benefits of brassinosteroid crosstalk. Trends Plant Sci. 17:594-605.

Dawson, C.J., and Hilton, J. 2011. Fertilizer availability in a resource limited world: production and recycling of nitrogen and phosphorus. Food Policy.36:814-822.

Defra, 2010. The Fertiliser Manual (RB209). Department of the Environment, Food and Rural Affairs, TSO (The Stationary
Office). 252 p. http://www.defra.gov. uk/publications/2011/03/25/fertilisermanual-rb209/

Dobrikova, A. G., Vladkova, R. S., Rashkov, G. D., Todinova, S. J., Krumova, S. B. and Apostolova, E. L. 2014. Effects of exogenous 24-epibrassinolide on the photosynthetic membranes under nonstress conditions. Plant Physiol. \&Biochem. 80:75-82.

Edwards, T., Paul, W., Sylvester, Roger, and Davey, J. 2015. Routes to improving the phosphorus use in arable crop production. Research Review No 83, AHDB Cereals and Oilseeds

Gadallah, M.A.A., 2000. Effects of indole-3acetic acid and zinc on the growth, osmotic potential and soluble carbon and $\mathrm{N}$ components of soybean plants growing under water deficit. J. Arid Environ. 44:451-467.

Gomez, K.A., and Gomez, A.A. 1984. Statistical Procedures for Agricultural Research. $2^{\text {nd }}$ Edition. An International Rice Research Institute Book. A Wiley Interscience Publication. John Wiley and Sons, New York.

Guppy, C.N., Menzies, N.W., Moody, P.W. and Blamey, F.P.C. 2005. Competitive sorption reactions between phosphorus and organic matter in soil: a review. Austr. J. Soil Res. 43:189-202

Gyaneshwar, P., Kumar, G.N., Parekh, L.J. and Poole, P.S. 2002. Role of soil microorganisms in improving $\mathrm{P}$ nutrition of plants. Plant and Soil.245:83-93.

Halliday, K.J., 2004. Plant hormones: the interplay of brassinosteroids and auxin. Curr. Biol. 14: R1008-R1010.

Hao, X., Cho, C. M., Racz, G. J. and Chang, C. 2002. Chemical retardation of phosphate diffusion in an acid soil as affected by liming. Nutr.Cycling Agroecosyst., 64:213-224.

Haubrick, L.L., and Assmann, S.M. 2006. BR and plant function: some clues, more puzzles. Plant Cell \& Environ., 29:446457.

Havlin, J. L., Tisdale, S. L., Beaton, J. D. and 
Nelson, W. L. 2007. Soil fertility and fertilizers: An Introduction to Nutrient Management. Pearson Education Inc., Upper Saddle River, New Jersey 07458, U.S.A.

Hayat, S., Ahmad, A., Mobin, M., Fariduddin, Q., and Azam, Z.M. 2001. Carbonic anhydrase, photosynthesis and seed yield in mustard plants treated with phytohormones. Photosynthetica, 39(1):111114.

Hayat, S., Mori, M., Fariduddin, Q., Bajguz, A. and Ahmad, A. 2010. Physiological role of brassinosteroids: an update. Ind. J. Plant Physiol. 15:99-109.

Hedge, D.M., Sudhakar, B.S.N., Rana, D.S. and Vyas, A.K. 2012. Agronomic research on oilseeds in India: An overview. Indian J. Agron. 57:58-62.

Hola, D., 2011. BR and photosynthesis. In: BR: A class of plant hormones (Editors Shamsul Hayat and Aqil Ahmad). ISBN: 978-94-007-0188-5 DOI: 10.1007/97894-007-0189-2. Springer Dordrecht Heideberg London New York p: 243-288.

Jones, D.L., and Eva, O. 2011. Solubilization of $\mathrm{P}$ by soil microorganisms. EL Bunemann et al., (eds). $\mathrm{P}$ in action-Biological processes in soil $\mathrm{P}$ cycling. Soil Biol. 26:169-198.

Kalinova, J., 2010. Alleleopathy and organic farming: Sustainable Agril. Reviews 3, DOI 10.1007/978-90-481-3333-8_14. Springer Science + Business Media

Khaswa, S.L., Dubey, R.K., Singh, S. and Tiwari, R.C., Singh, I. 2014. Balance sheet of soil nitrogen and phosphorus vis- a-vis soybean productivity under different levels and sources of phosphorus and plant growth regulators in sub humid Rajasthan. Res. on Crops.15:590-598.

Olsen, S.R., Cole, C.W., Watanade, F.S. and Dean, L.A. 1954. Estimation of available phosphorus in soil by extraction with sodium bicarbonate, USDA, Washington, D.C. Circular No. 239 p.13.

Pathak, H., Mohanty, S., Jain, N. and Bhatia, A. 2010. Nitrogen, phosphorus and potassium budgets in Indian agriculture. Nutr.Cycling Agroecosyst. 80:287-299.

Rathke, G.W., Behrens, T. and Diepenbrock, W. 2006. Integrated $\mathrm{N}$ management strategies to improve seed yield, oil content and $\mathrm{N}$ efficiency of winter oilseed rape (Brassica napus L.): A review. Agril. Ecosyst. Environ. 117:80-108.

Richards, L.A., 1968. Diagnosis and Improvement of Saline and Alkaline Soils. USDA Handbook No. 60, Oxford and IBH Pub. Co., New Delhi 97-98.

Richardson, A.E., 2001. Prospect for using soil microorganisms to improve the acquisition of phosphorus by plants. Austr. J. Plant Physiol., 28:897-907.

Tandon, H.L.S., 2007. Soil nutrient balance sheets in India: Importance, status, issues and concerns.

TSI. 2014. Sulphur in Indian agriculture. Correction of sulphur deficiency in Indian agriculture. The Sulphur Institute 1020, $19^{\text {th }}$ Street, NW Suite 520 Washington DC 20036 USA. www.ipni.net

\section{How to cite this article:}

Dubey, R.K., R.C. Dhaker, S.L. Mundra, R.C. Tiwari, S.K. Dubey and Reena Dubey. 2017. Response of Indian mustard to Nutrients and Plant Growth Regulators: The Influence on Yield, Available Soil P Balance and P Recycling through Residues. Int.J.Curr.Microbiol.App.Sci. 6(8): 3319-3331. doi: https://doi.org/10.20546/ijcmas.2017.608.396 